\title{
Analysis of consumers' negative perceptions of health tracking in insurance - a value sacrifice approach
}

\author{
Antti Talonen and Jukka Mähönen \\ Faculty of Law, University of Helsinki, Helsinki, Finland, and \\ Lasse Koskinen and Päivikki Kuoppakangas \\ Faculty of Management and Business, Tampere University, Tampere, Finland
}

Negative perceptions of health tracking

\begin{abstract}
Purpose - This paper explores and identifies customer-value-related sacrifices that consumers attach to interactive health/life insurance. This paper aims to increase understanding of why individual consumers are not willing to embrace behaviour-tracking-based insurance applications.

Design/methodology/approach - The authors analysed data from a qualitative survey of Finnish insurance consumers who were not keen on adopting interactive insurance products.

Findings - Developed through thematic analysis, the framework presented in this paper illustrates consumers' value sacrifices on four dimensions: economic, functional, emotional and symbolic value.

Research limitations/implications - The framework and insights emerging in the study hold several implications related to increased understanding of consumers' perceptions of insurance and to developing interactive insurance services. In addition, this work provides a promising foundation and avenues for further considerations related to digital ethics in insurance.

Originality/value - To the best of the authors' knowledge, this paper is the first piece applying a value sacrifice perspective in studying consumers' unwillingness to adopt interactive insurance products.
\end{abstract}

Keywords Customer value, Digital ethics, Insurtech, Interactive insurance, Smart insurance

Paper type Research paper

\section{Introduction}

In the past few years, insurance scholars have produced a reasonable amount of material on digitalisation and the vast possibilities of the new technologies introduced in the insurance sector. These implementations have paid particular attention to the consumer interface (Maas and Rüfenacht, 2018; Riikkinen et al., 2018). One illustration of the growing emphasis on customer orientation is the rise of digital application, which are often based on insured users' willingness to voluntarily share data on their behaviour with the insurance company

(C) Antti Talonen, Jukka Mähönen, Lasse Koskinen and Päivikki Kuoppakangas. Published by Emerald Publishing Limited. This article is published under the Creative Commons Attribution (CC BY 4.0) license. Anyone may reproduce, distribute, translate and create derivative works of this article (for both commercial and non-commercial purposes), subject to full attribution to the original publication and authors. The full terms of this license may be seen at http://creativecommons.org/ licences/by/4.0/legalcode

Funding: This project has received funding from the European Union's Horizon 2020 research and innovation program under Grant Agreement No. 825215.

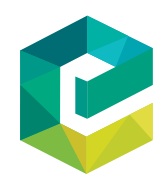

Received 13 May 2020

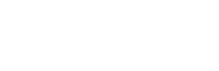

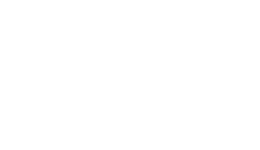

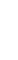


JICES

19,4

in real time via various types of wearable sensors (cf. Becher, 2016). Uptake is encouraged by offering the customer monetary rewards for behaviour that prevents risks from being actualised.

The landscape also features numerous people who remain unwilling to adopt and start using these applications (Voutilainen and Koskinen, 2017; McCrea and Farrell, 2018; cf. Baker, 2020). Even in a scenario of wearable technology being distributed to customers at no cost, only two-thirds of survey respondents expressed willingness to adopt tracking-based applications (Dart, 2015). Earlier research suggests that individuals' willingness to embrace new technologies for financial services in general is influenced by their perception of value for the customer (Kim et al., 2007; Kim et al., 2017; Laukkanen, 2007). In other words, someone who perceives himself or herself as getting greater value from the new technology or digital mechanism will adopt it. Applying such thinking about customer value, we presume that the adoption of new digital insurance applications is also influenced by individuals' perceived value sacrifices. In other words, those who choose not to adopt tracking-based insurance applications perceive this technology as not generating increased customer value relative to the older approach, and change, uncertainty, etc., all entail sacrifices. Notwithstanding the extent and import of this phenomenon, most research into value perceptions' influence on adoption of new digital applications has focused on the banking industry, while research and understanding of the phenomenon in the insurance industry has remained limited.

Proceeding from these premises, we undertook to explore and identify the customervalue-related sacrifices that consumers attach to interactive health/life insurance. With the aim of increasing understanding of why individual consumers are unwilling to adopt behaviour-tracking-based insurance applications, we analysed a body of qualitative survey data from Finnish insurance users who were not interested in adopting interactive health/ life insurance products. This paper describes the framework developed in our study, which presents consumers' value sacrifices on four distinct dimensions of value, the economic, functional, emotional and symbolic. The framework and findings we present have several implications for better understanding of consumer perceptions of insurance, which could inform the development of interactive insurance services. In addition, the study provides insights that offer a basis for further consideration of digital ethics in the insurance domain.

\section{Customer value and insurance}

Customer value is commonly defined as the customer's perception of the balance between what is received and what is forgone or not received in the relevant transaction(s). Clearly, the construct thus encompasses perceptions of (positive) value and also (on the negative side of the scale) of sacrifices. Both come in several forms, with customers able to perceive value and corresponding sacrifices that range from highly utilitarian concerns to the hedonic end of the continuum. More nuanced views conceptualise value on multiple dimensions, with one popular approach being a typology with dimensions of economic and functional value, extending further to "emotional value" and identity-related "symbolic value" (Rintamäki et al., 2007).

Such categorisation schemes abound, with the concept of customer value and customer orientation in general having long held pride of place in marketing scholars' discussions. Researchers have turned their eyes specifically to the insurance context only quite recently. In turn, the discipline's traditional ethos related to risk theory and actuarial mathematics (Beard et al., 1984; Daykin et al., 1994) has been supplemented by increased focus on customer orientation in response to recent developments. In particular, Maas and Rüfenacht (2018) have identified three interrelated though distinct trends in the insurance field that 
speak in favour of putting specific emphasis on customer-centred operations and, especially, customer value: low levels of consumer trust in insurance companies, extension of the customer's role from mere consumer of the service to active co-creator of value and consumers' high standards for digital tools (arising from familiarity with them). These perspectives can be seen as particularly important and relevant in the context of interactive health/life insurance services. Firstly, customers' voluntary sharing of their sensitive health data with the company demands a high level of trust. Also, interactive insurance offers the consumer an active role in influencing premium levels via his or her behaviour so is, by nature, a quintessential example of value co-creation. Thirdly, to get customers interested in new ways to insure oneself, one must understand consumers' high expectations for technological applications and interfaces.

\section{Interactive insurance applications}

Interactive health/life insurance is a mechanism to encourage individuals to live a healthier life. It is based on a dynamic pricing model wherein information about a customer's behaviour is collected and particular behaviour can lead to discounts on that customer's insurance premiums or to other benefits. Actual health and living habits can be tracked via wearables such as fitness bracelets provided to the insured. The approach is grounded in research suggesting that giving customer an opportunity for lower premiums and encouraging them to live a healthier life should have an impact on the size and likelihood of claims (cf. Lambert et al., 2009; Patel et al., 2011), and it has its parallels in initiatives established for other sorts of insurance, such as car and liability insurance (e.g. Desyllas and Sako, 2013; Litman, 2005).

Given the theoretical underpinnings outlined above, the characteristics and nature of interactive insurance should represent vast opportunities to facilitate customer value creation among insurance users. Interactive insurance has been identified as possessing a co-creative and empowering character (cf. Fuchs et al., 2010; Hair et al., 2016; Harrison, 2002) that should influence value creation on several levels. Firstly, it confers increased control over the premiums paid. Secondly, the game-like nature of the application, wherein rewards are given upon desired behaviour, can be expected to stimulate feelings of joy. Finally, representing a healthy and sporty lifestyle, interactive insurance could be seen as offering means for individuals to further develop, maintain and express their sense of self.

\section{Data and methodology}

Interactive insurance is growing more and more popular globally and has been characterised as expressing one of the main trends guiding the development of insurance services (Kumar and Yellampalli, 2018). Among the success stories and pioneers of its development has been discovery with its health insurance scheme in South Africa (Patel et al., 2010, 2011). In contrast, insurers in our research context, Finland, have displayed caution, going no further than establishing pilot programmes. As a market where interactive insurance is still in its infancy, Finland serves as fertile ground for studying consumers' unwillingness to embrace such initiatives.

Our exploration of Finnish people's opinions on tracking-based insurance began with a survey, using a questionnaire that addressed insurance in general, life insurance and nonlife insurance. For this survey, conducted in autumn 2016, the sample was representative with regard to respondents' income, relationships with banks and insurers, residence, profession and other demographics. In all, 127 members of this group responded. In addition to the "basic sample," we solicited data from students pursuing a business degree at Finland's University of Tampere. This gave us 69 further responses, representing highly 
JICES

19,4

educated young people (with an average age of 24 , while that for the basic sample was 58). For the analyses we extracted all the respondents who indicated they were not willing to start using the new interactive insurance applications. Willingness to start using was measured with a scale from 1 to $6(1=$ definitely; $6=$ never $)$. Respondents answering 4,5 or 6 were included into the final dataset to be analysed, which included all together 62 respondents ( 52 from the basic sample, 10 from the students).

In the absence of an existing framework that describes consumers' perceived value sacrifices in the context of insurance services, we used an exploratory technique aimed at elicitation, with open-ended questions. The respondents - people who had indicated in earlier responses that they were not interested in using interactive health/life insurance - were given an opportunity to think through the items freely and evaluate why they were not willing to start using interactive life/ health insurance (cf. Geer, 1988; Reja et al., 2003). The open-ended items were created not to represent certain scientific theory, but to capture contextual aspects of both insurer-related factors (such as data protection) and consumer-linked ones (e.g. personal health). They were developed in cooperation of two scholars (one of the authors and his colleague, who both have a long professional and academic experience in the insurance industry) who discussed possible themes several times and iteratively developed the final group of seven themes (cf. researcher triangulation, e.g. Jonsen and Jehn, 2009). These themes included: the quality of the company's decision-making, cyber-security, the rewards gained through sharing information, the benefits and the terms for receiving them, one's state of health, the tracking process and other elements. The last theme of "other elements" was developed to give respondents a free space to describe views which would not go under the six other themes. The aim was to minimize the possibility that important views would not become visible.

Our choice of data-analysis method was thematic analysis, wherein the principle is to identify various patterns in the data and report them in the form of the themes that emerge. The analysis process, as described by Braun and Clarke (2006), among others, begins with identifying features in the data, which are coded on the basis of the themes present. The process continues with second-order analysis, in which similarities or common characteristics are identified among the codes, whereupon concepts are developed accordingly. The full framework emerging in our study is shown in Table 1 and discussed dimension-specifically below.

This thematic analysis approach (Attride-Stirling, 2001; Tuckett, 2005) gave us the tools to construct a framework of value sacrifices that inhibit consumers from adopting interactive insurance services. The iterative analysis process produced 20 first-order elements (initial themes) and eight second-order ones (final concepts). In both phases of the analysis (the themes' and the concepts' development), we used researcher triangulation (Jonsen and Jehn, 2009). Accordingly, two of the authors worked independently at first, then discussed their findings and data analysis. This interaction helped validate the themes, concepts and analysis process.

We construed the data for analysis in light of approaches considering the concept of customer value, particularly with regard to its dimensions per Rintamäki et al. (2007): economic, functional, emotional and symbolic. In addition, we used literature on e-health and health-data tracking. Leaning on prior research while not deductively testing it, our approach can be regarded as abductive (Dubois and Gadde, 2002).

\section{Findings}

Our data analysis identified perceived value sacrifices on all four dimensions of customer value in the typology. As we elaborate on the findings below, we consider each of these in detail. 


\begin{tabular}{|c|c|c|c|}
\hline Dimension of value & Themes (second order) & Concepts (first order) & \\
\hline Economic value & $\begin{array}{l}\text { The risks related to } \\
\text { customer-company } \\
\text { interaction } \\
\text { A challenging process for } \\
\text { obtaining rewards }\end{array}$ & $\begin{array}{l}\text { The insurance company's economic aims cannot } \\
\text { be trusted } \\
\text { Exercising control is expensive } \\
\text { "Little things" reduce the bonus } \\
\text { True monetary rewards are not within reach for } \\
\text { normal people }\end{array}$ & health tracking \\
\hline Functional value & $\begin{array}{l}\text { Excessively complex logic } \\
\text { behind smart life } \\
\text { insurance } \\
\text { The application not being } \\
\text { perceived as useful }\end{array}$ & $\begin{array}{l}\text { Health is a challenging target of control and } \\
\text { influence } \\
\text { The insurance terms are complicated } \\
\text { Interactive health/life insurance does not increase } \\
\text { access to insurance services } \\
\text { Interactive health/life insurance does not make it } \\
\text { more convenient to track one's health }\end{array}$ & \\
\hline Emotional value & $\begin{array}{l}\text { Lack of trust in insurance } \\
\text { companies }\end{array}$ & $\begin{array}{l}\text { Insurance companies can draw their own } \\
\text { conclusions related to premiums and claims } \\
\text { Insurance companies do not care about changes } \\
\text { in a customer's life situation } \\
\text { An insurance company may sell the data to } \\
\text { outsiders } \\
\text { Control of the data is lost upon switching insurer } \\
\text { An insurance company's staff could abuse their } \\
\text { position }\end{array}$ & \\
\hline & $\begin{array}{l}\text { Unpleasant emotions } \\
\text { related to tracking }\end{array}$ & $\begin{array}{l}\text { Tracking is perceived as laborious and } \\
\text { complicated } \\
\text { Tracking is perceived as a responsibility }\end{array}$ & \\
\hline $\begin{array}{l}\text { Symbolic } \\
\text { value }\end{array}$ & $\begin{array}{l}\text { The app not assisting in } \\
\text { development of self- } \\
\text { identity } \\
\text { The app not aiding in } \\
\text { maintaining continuity of } \\
\text { self-identity }\end{array}$ & $\begin{array}{l}\text { Use of the application restricts freedom of choice } \\
\text { Use of the application detracts from self- } \\
\text { acceptance } \\
\text { The company's interpretation of the behaviour is } \\
\text { in conflict with the sense of identity built by } \\
\text { using the application } \\
\text { Use of the application stands in contradiction to } \\
\text { the self-identity developed } \\
\text { Encouragement may support or be detrimental to } \\
\text { the self-identity developed, depending on one's } \\
\text { life situation }\end{array}$ & $\begin{array}{r}\text { Table 1. } \\
\text { Overall framework } \\
\text { developed in the } \\
\text { study }\end{array}$ \\
\hline
\end{tabular}

\section{Economic value}

Economic value involves monetary benefits gained and perceived by the customer. These may take the form of savings and discounts or of getting more for the same price (Chandon, 2002). In this regard, the "main idea" of interactive health/life insurance is dynamic pricing that the customer can influence by behaving and living healthily. Accordingly, creating economic value for the customer as manifested in lower premiums is at the heart of interactive insurance. However, as illustrated below, our data indicate that consumers may not always echo that assessment. They may consider the promised economic value unobtainable. At the same time, the individual is aware of the need to provide personal health information to the insurance company. Therefore, some customers may perceive an economic value sacrifice - giving more without getting rewarded - and hence be unwilling to adopt the new technology. We will now elaborate on these perceptions, presented in Table 2 . 


\section{JICES 19,4}

\begin{tabular}{|c|c|c|}
\hline Concepts (second order) & $\begin{array}{l}\text { Economic value } \\
\text { Themes (first order) }\end{array}$ & Illustrative quotes \\
\hline \multirow[t]{2}{*}{$\begin{array}{l}\text { The risks related to } \\
\text { customer-company } \\
\text { interaction }\end{array}$} & $\begin{array}{l}\text { The insurance company's } \\
\text { economic aims cannot be } \\
\text { trusted }\end{array}$ & $\begin{array}{l}\text { "Insurance companies have only one goal: } \\
\text { to increase their own profits. They are not } \\
\text { making objective decisions but using all } \\
\text { means possible to increase the level of } \\
\text { premiums" }\end{array}$ \\
\hline & Exercising control is expensive & $\begin{array}{l}\text { "If you don't accept the insurance } \\
\text { company's decision, often the only way to } \\
\text { change it is via the courts" }\end{array}$ \\
\hline \multirow[t]{2}{*}{$\begin{array}{l}\text { The challenging process } \\
\text { for obtaining rewards }\end{array}$} & "Little things" reduce the bonus & $\begin{array}{l}\text { "When tracking is used, minor factors } \\
\text { may decrease the amount of the bonus" }\end{array}$ \\
\hline & $\begin{array}{l}\text { Monetary rewards are not } \\
\text { within reach for normal people }\end{array}$ & $\begin{array}{l}\text { "Premiums can be lowered only by the } \\
\text { behaviour of a professional athlete" }\end{array}$ \\
\hline
\end{tabular}

Risks related to customer-company interaction. The first reason for consumers to conclude that the economic benefits are beyond reach is perceived risks related to the interaction with the insurance company. These risks were articulated in the data at least two distinct ways. Firstly, the consumer may not trust the company's aims. Possibly reflecting general distrust of the insurance industry and its players (Bieck and Tjioe, 2015), one may perceive "the right behaviour brings lower premiums" as only a story planted to increase the profits of the company, not to benefit the customer. One of the respondents explained in these words:

Insurance companies have only one goal: to increase their own profits. They are not making objective decisions but using all means possible to increase the level of premiums.

Secondly, consumers might conclude that the only way to settle a disagreement with the insurance company's decision is in court. A sense of powerlessness relative to a big company wherein “events are out of one's control" (Bunker and Ball, 2009, p. 268) may lead to concerns that safeguarding one's interests may require lots of money, time and effort. One respondent expressed this idea thus:

If you don't accept the insurance company's decision, often the only way to change it is via the courts.

\section{Challenging process of earning rewards}

The second reason for seeing economic sacrifice is expectations for the interactive tracking process to prove challenging in terms of actually gaining economic rewards. This was indicated in the data in at least two ways. Firstly, an individual might worry about minor factors getting too much weight in the overall evaluation of behaviour and the related premium, as in this response:

When tracking is used, minor factors may decrease the amount of the bonus.

Secondly, we noticed respondents concluding that the level of a desired behaviour that triggers lower premiums is hard to reach. The discouraged individual may view interactive insurance, accordingly, as being for people who are systematic and professional in their sport pursuits and healthy living habits. One respondent expressed this sentiment thus:

Premiums can be lowered only by the behaviour of a professional athlete. 
Functional value, related to utilitarian benefits, such as convenience or a product's usefulness (Rintamäki et al., 2007), gets created when there is a perception that one's tasks will be accomplished better via the service/product or that it is easy to consume/ use. In the data, respondents raised the matter of functional-value-related sacrifices under two themes, presented in Table 3 and discussed below: the logic and usefulness of interactive insurance.

\section{Complicated logic}

When discussing functional value, several scholars refer to the convenience (related to time, effort, etc.) of consuming a service or purchasing a product (Baker et al., 2002; Rintamäki et al., 2006). Related value sacrifices were visible in the survey data in at least two respects. Firstly, respondents' viewed health as tricky to influence. For instance, any of various inherited diseases/conditions may reduce the effect of healthy living habits on one's overall health. This adds complexity to interactive insurance in the context of health/life insurance. One respondent offered these musings:

Driving behaviour is dependent on the individual. Getting old or sick cannot be influenced [...]. The 'genetically handicapped' are the outcasts of tomorrow, not appreciated in society even if they eat carrots and run marathons.

Secondly, several participants raised the issue of insurance terms getting too complicated. This may, in part, echo a general perception of insurance contracts, which have been found very hard to understand (Peverelli and de Feniks, 2010). If this complexity is coupled with the logic behind the interactive insurance being challenging to understand, as mentioned above, reading the contract may prove all the more daunting. One respondent summarised:

From an individual's point of view, the terms of the insurance contract easily become too complicated.

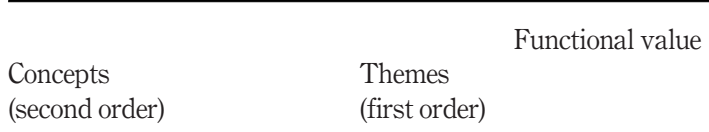

The excessively complex logic behind smart life insurance

The application not being perceived as useful
Health is a challenging target of control and influence

The insurance terms are complicated

Interactive health/life insurance does not increase access to insurance services

Interactive health/life insurance does not make it more convenient to track one's health
Illustrative quotes

"Driving behaviour is dependent on the individual. Getting old or sick cannot be influenced .... The "genetically handicapped" are the outcasts of tomorrow, not appreciated in society even if they eat carrots and run marathons" "From an individual's point of view, the terms of the insurance contract easily become too complicated"

"As far as I understand it, my age prevents me from purchasing life insurance. At least the previous [insurance plans] have stopped." "Today's technology and medical centres provide good possibilities [for tracking one's health]" perceptions of health tracking 
JICES
19,4

\section{Perceptions that the app is not useful}

The literature suggests that someone may adopt new methods if feeling that the technology lets him or her perform tasks better (Bhattacherjee and Sanford, 2006; Cheung and Vogel, 2013). This perceived usefulness is one aspect of functional customer value. Our data indicate that people may identify usefulness-related sacrifices in at least two ways. Firstly, for members of a group who may not have been able to obtain health/life insurance before, a "smart" insurance product does not increase insurance services' inclusiveness relative to their earlier situation:

As far as I understand it, my age prevents me from purchasing life insurance. At least the previous [insurance plans] have stopped.

It is important to recognise, though, that negative perceptions in this regard may be connected most strongly with discouraging experiences and do not necessarily reflect the actual characteristics of the smart insurance products offered. For example, young drivers may receive significant reductions in premiums when proving that they are driving safely (Soleymanian et al., 2019).

The second sacrifice type identified is a sense that smart insurance offers no new features or tools that people could use to perform current tasks better. For example, one may see traditional ways to track health (visiting a physician, using sport watches without sending the information to an insurance company, etc.) as perfectly sufficient. One informant offered this conclusion about health-tracking:

Today's technology and medical centres provide good possibilities.

\section{Emotional value}

Sheth et al. (1991) define emotional value as "perceived utility derived from an alternative's capacity to arouse feelings or affective states" (p. 161). These may include emotions connected with entertainment and playfulness (Mathwick et al., 2001), exploration (Rintamäki et al., 2006) or aesthetics and pleasure (Jung Choo et al., 2012). Functional-valuerelated sacrifices were identified in the data under two themes (Table 4): lack of trust in the insurance company and unpleasant emotions around tracking.

\section{Lack of trust in the insurance company}

Lack of consumer trust is a real, recognised challenge for insurance companies. By recent estimates, only $43 \%$ of people trust the insurance industry in general, globally. Respondents raised associated concerns in several ways. Firstly, some consumers may not trust insurance companies to make fair decisions on customers' claims or premium levels. In the context of health-data tracking, this manifests itself in concerns about insurers' ways of interpreting the data. Gidaris (2019) offers an example of this prejudice, asking: "Could this data be used by interactive life insurance companies to establish a breach of contract, when, perhaps, an individual's health and fitness data can be connected, however loosely, to newly developed medical conditions or diseases?” (p. 135). Our data set contains this example:

The insurance company has a supreme right and ability to reach their own conclusions.

Secondly, interactive insurance is based on a concept of continuous tracking, which requires consumers' long-term engagement and a commitment to living as the insurance company dictates (Ledger and McCaffrey, 2014). In the real world, customers may recognise that, while they are, in principle, capable of living in the desired manner, situations or times in life may arise in which they are not able to do so. Thus, doubt may arise about whether the insurance company will interpret stretches of relative inactivity, even short ones, as bad 


\begin{tabular}{ll}
\hline $\begin{array}{l}\text { Concepts } \\
\text { (second order) }\end{array}$ & $\begin{array}{l}\text { Themes } \\
\text { (first order) }\end{array}$ \\
\hline Lack of trust in & $\begin{array}{l}\text { Insurance companies can draw } \\
\text { their own conclusions related } \\
\text { to premiums and claims } \\
\text { Insurance companies do not } \\
\text { care about changes in a } \\
\text { customer's life situation }\end{array}$ \\
\end{tabular}

An insurance company may sell the data to outsiders Control of the data is lost upon switching insurer

An insurance company's staff could abuse their position

Tracking is perceived as laborious and complicated Tracking is perceived as a responsibility
Illustrative quotes

"The insurance company has a supreme right and ability to reach their own conclusions"

"When I purchased the insurance, my activity may have been at a good level. However, there are many [times of] challenges and hardship in life when taking care of one's health may not get that much attention. This may, in turn, lead to a situation the insurance company interprets as me having not fulfilled the insurance contract in terms of my activity"

"The data will be sold on to third parties at a later stage"

"If I change insurance provider often, my data will be in everybody's hands. Not good!"

"Courts are handling cases in which civil servants have intruded to look at information related to other people. When this reaches court, the damage and harm has already occurred and rumours about people have been set in motion. Therefore, it doesn't help to go to court anymore" "[Tracking] feels so laborious and complicated"

"What does this application obligate me to do? How and how often will health be checked?"

Table 4. Emotional value

behaviour that could immediately decrease the amount of rewards (cf. Langley, 2015). The following extract from our data set expresses this:

When I purchased the insurance, my activity may have been at a good level. However, there are many [times of] challenges and hardship in life when taking care of one's health may not get that much attention. This may, in turn, lead to a situation the insurance company interprets as me having not fulfilled the insurance contract in terms of my activity.

Thirdly, there are suggestions that insurance companies are less encumbered by restrictions to utilisation of customers' health data than are traditional health-care providers, who are guided by patient confidentiality laws. For example, examining US markets, Langley (2015) stated that insurance companies have been given an opportunity to monetise their accumulated customer health data by selling the data to third parties. A fear of such actions by insurance companies and assumptions about their policies was manifested in our data. Though selling the data is subject to the customer's acceptance (agreeing with certain terms), consumers perceive themselves as not having control over the process. One respondent expressed this as follows:

The data will be sold on to third parties at a later stage. 
JICES

19,4

472

Also, losing control of one's personal health data (Crawford et al., 2015) may occur in conjunction with a change of insurance provider. Some fear that the data remain available to the previous provider too in these circumstances. Switching provider multiple times could leave numerous parties with the hapless consumer's information. One respondent offered this extreme example:

$$
\text { If I change insurance provider often, my data will be in everybody's hands. Not good! }
$$

A final target of lack of trust identified is individual personnel of the insurance company. At issue here is the possibility of staff misusing a position that gives them access to customers' often sensitive personal health data. One respondent addressed the issue of such abuse and its consequences by saying:

Courts are handling cases in which civil servants have intruded to look at information related to other people. When this reaches court, the damage and harm has already occurred and rumours about people have been set in motion. Therefore, it doesn't help to go to court anymore.

\section{Unpleasant emotions surrounding tracking}

One might expect interactive health/life insurance evoking game-like aspects to stimulate the consumer in a manner that increases excitement levels during consumption of insurance services (cf. Hofacker et al., 2016; Sardi et al., 2017). Our data indicate that, on the contrary, some consumers perceive these applications as not very exciting in at least two respects. Firstly, tracking is deemed burdensome (cf. Similä et al., 2018), with one of the respondents stating that tracking feels so laborious and complicated.

Secondly, some may see it as a responsibility rather than a mentally stimulating opportunity. According to Lupton (2016), this is particularly likely in circumstances wherein the tracking is not impelled by the individual's own motivation but "pushed" or encouraged by a third party. This idea was brought up in one of the respondents' comments thus:

What does this application obligate me to do? How and how often will health be checked?

Symbolic value. The symbolic dimension, presented below in Table 5, brings in a social aspect of value perceptions. The customer's interaction with the product or service acts as a social symbol that is employed in building and maintaining one's self-identity and in expressing it to others (Rintamäki et al., 2006). To address adoption and use of new technologies, Carter and Grover (2015, p. 931) use the term "IT-identity," for "the extent to which an individual views use of an IT as integral to his or her sense of self." The role of technology utilisation in identity development has recently been recognised specifically in the context of wearable fitness devices and health-tracking (Giddens et al., 2016). Our analysis did identify several factors related to developing and maintaining identity; however, the respondents did not directly address expression of identity. We discuss this further in the next section of the paper.

Developing self-identity. Self-development-related sacrifices were articulated in our data in at least two distinct ways. Firstly, when individuals are encouraged or even forced to behave in certain ways in exchange for rewards, they may be constrained from making their own choices in life (cf. Baker, 2020) and developing their identity accordingly. Perceived loss of freedom is indeed visible in the reasons cited for not adopting a tracking-based health insurance service. Respondents stressed the value of respect for individual-level choices and for decisions that are not necessarily rational - even a fundamentally unhealthy habit may be a choice that should be left for the individual. Accordingly, they saw tracking-based 


\begin{tabular}{lll} 
& \multicolumn{2}{c}{ Symbolic value } \\
$\begin{array}{l}\text { Concepts } \\
\text { (second order) }\end{array}$ & $\begin{array}{l}\text { Themes } \\
\text { (first order) }\end{array}$ & Illustrative quotes \\
\hline
\end{tabular}

\section{Negative perceptions of health tracking}

The app not assisting in development of selfidentity

Use of the application restricts freedom of choice

Use of the application detracts from selfacceptance

The company's interpretation of the behaviour is in conflict with the sense of identity built by using the application Use of the application stands in contradiction to the self-identity developed

Encouragement may support or be detrimental to the self-identity developed, depending on one's life situation
"Smoking cigarettes is, of course, unhealthy, but one needs to have the freedom to make stupid decisions"

"As a young woman, you already face so much pressure related to your living habits and looks. It feels disturbing that you would be penalised for gaining a few extra kilos or not exercising enough. There are many individuals who can't do anything about their health"

"Whatever information is gained can be interpreted in a way that serves the insurance company's own purposes. [Let me] exaggerate: one who follows healthy living habits can be made to look like an orthorexic, who can be further categorised as a mental-health patient" "My problem with the application is the definition of healthy living habits. If the insurance company agrees with me, I would be interested in using the application. If they define healthy living habits according to the official view, we don't agree. For example, [what makes a] healthy diet is one thing on which our views probably do not match. So I would get to pay more for my insurance even though I'm living a healthy life and don't get sick. Merely because my view of a healthy life differs from the official one. This little fact destroys the incentives on my part”

"When I purchased the insurance, my activity may have been at a good level. However, there are many [times of] challenges and hardship in life when taking care of one's health may not get that much attention. This may, in turn, lead to a situation the insurance company interprets as me having not fulfilled the insurance contract in terms of my activity"
Table 5. Symbolic value

applications as limiting individuals' freedom of choice and, therefore, not worth adopting, as this extract illustrates:

Smoking cigarettes is, of course, unhealthy, but one needs to have the freedom to make stupid decisions.

Secondly, identity development that cultivates self-esteem (Rintamäki et al., 2006, 2007) is likely to involve a self-acceptance process too (Chen et al., 2019; Mohr and Fassinger, 2003). In certain circumstances, one may find that smart insurance products derail this process. Placing emphasis on healthful living habits and a healthy body can be interpreted as criticism of individuals who face natural challenges with, for example, weight. To support healthy development of individuals' identity and their self-acceptance process, one should approach these sensitive themes with utmost caution and prudence, as this comment from our data highlights: 
JICES

19,4

As a young woman, you already face so much pressure related to your living habits and looks. It feels disturbing that you would be penalised for gaining a few extra kilos or not exercising enough. There are many individuals who can't do anything about their health.

\section{Maintaining one's self-identity}

People have a recognised need not just to develop their identity but also to engage in activities that maintain the identity built (Csíkszentmihályi and Rochberg-Halton, 1981). Distraction from this maintenance work can create psychological challenges for the individual (Kamptner, 1989; Meister et al., 2015), and we identified at least three ways in which our data articulated associated value sacrifices in relation to interactive insurance. Firstly, one might presume that the insurance company will interpret every kind of behaviour in its own favour. In this logic, even people who behave as expected get made to resemble something else. One respondent expressed this reasoning thus:

Whatever information is gained can be interpreted in a way that serves the insurance company's own purposes. [Let me] exaggerate: one who follows healthy living habits can be made to look like an orthorexic, who can be further categorised as a mental-health patient.

Secondly, definitions of healthy living may vary. It is entirely possible for a person to have learnt a definition that differs from the insurance company's. Furthermore, if that internalisation has informed development of the person's identity, the company's view may distract from the maintenance process. Awareness of this issue may influence one's willingness to adopt an interactive insurance app, as was indicated in our data:

My problem with the application is the definition of healthy living habits. If the insurance company agrees with me, I would be interested in using the application. If they define healthy living habits according to the official view, we don't agree. For example, [what makes a] healthy diet is one thing on which our views probably do not match. So I would get to pay more for my insurance even though I'm living a healthy life and don't get sick. Merely because my view of a healthy life differ from the official one. This little fact destroys the incentives on my part.

Thirdly, even someone whose identity has underpinnings of healthy living habits may experience hard times and challenging life circumstances. For instance, it might be difficult to gather strength for sports after a loved one has died. If the insurance company interprets these circumstances in such a way that the person has failed to reach the goals stated in the contract, the self-identity developed may suffer. A quotation from earlier in the paper about priorities is telling in this regard: when someone is experiencing trouble and complexity:

[...] taking care of one's health may not get that much attention. This may, in turn, lead to a situation the insurance company interprets as me having not fulfilled the insurance contract in terms of my activity.

\section{Discussion and conclusions}

The study contributes to scientific discourse in several ways. Firstly, we believe it to be the first application of the customer value sacrifice approach to considering consumers' unwillingness to take up smart insurance technology. Moreover, the tentative framework enriches understanding of the customer-perceived sacrifices. Our outputs support the conclusion that in the rapidly changing digital business environment of the insurance industry, it is vital that companies account for the customer perspective (cf. Maas and Rüfenacht, 2018). Finally, this work paves the way for analysing and identifying specific 
value sacrifices that hinder adoption of new technological tools in other domains and industries.

The results add to scholarly understanding by showing that the perceived sacrifices extend beyond issues related to the interactive insurance and technology per se, to consumers' skills, attitudes and conceptions of these and the technology. This finding is consistent with research recognising these two facets in other domains and supports the conclusion that marketing communications programmes and education initiatives designed to create positive attitudes and increase skills among consumers could be expected to play an important role (cf. Shaikh and Karjaluoto, 2015; Wessels and Drennan, 2010).

Interestingly, we did not uncover evidence related to self-expression to others, which is another important facet of symbolic value recognised. Several factors may explain respondents' lack of elaboration on the social aspect of identity. For example, it could be argued that one seldom discusses insurance with friends and other social contacts. This is not an immutable truth, however: development of insurance-linked applications, interfaces and business models is geared more and more towards capturing and facilitating symbolic value for customers (Riikkinen et al., 2018), so the role of insurance-related symbols in consumers' self-expression may increase.

\section{Limitations and implications for future research}

As all research does, our study encountered several limitations, which light the way for future research. Firstly, the source data focused on Finnish insurance services' consumers. While it was useful to involve respondents from a country whose digitalisation is highly developed, it would be important to extend the analysis to an international data set. Such material should increase understanding of universal perceptions about interactive insurance and health-tracking in general and also culture- or country-specific perceptions of them.

Secondly, we recognize that open-ended survey questions built around the developed seven themes have certain limitations. When answering to a survey, researcher cannot ask, for example, clarifications from the interviewees. Hence, we suggest that additional qualitative interview data would be gathered, which could potentially aid researcher to identify fresh nuances compared to our results. However, this is not to invalidate our results, which are important in showing how sacrifices are actually perceived in all four customer value dimensions in the context of interactive insurance services. Thirdly, we concentrated on health/life insurance. We encourage taking a value sacrifice approach to other lines of insurance as well. Some key differences should be expected - related, for instance, to health data being considered more sensitive than data on certain other behaviour (e.g. driving).

Fourthly, in our data, only those respondents who indicated not being willing to adopt the applications, were directed to evaluate the reasons why it is the case. The respondents who indicated being willing to adopt the applications were directed to evaluate the reasons why they are willing to do this. Consequently, the data behind our analysis did not contain evaluations from those who may have been critical but were still ready to adopt the applications. This is one direction where we would encourage scholars to move in the future. In could be truly beneficial to increase our understanding by looking at the critical answers of the consumers with more positive attitudes towards interactive insurance services on a general level.

Fourthly, the aim of the paper was, via qualitative approach, to identify different barriers of adoption in light if value sacrifices. As such, the chosen analysis does not enable statistical tools for finding indication of the relative importance of the sacrifices. Consequently, we believe that it would be truly beneficial for future studies to move towards more quantitative statistical methods. These could even enable, for example, validation of a 
JICES

19,4

contextual specific measurement scale to study interactive insurance services with a large dataset. We also believe that our developed intellectual framework can act as good basis for the quantitative analyses.

Fifthly, and alongside contextual applications, the results open interesting avenues for ethics research. While our focus was not on ethics questions, the findings and data provide a solid foundation for efforts in that direction. Several themes emerged that exemplify the importance of ethics considerations. For example, who owns the data after gathering, and what are the consequences if consumers lose control of their health information? Furthermore, with health being tricky to track and measure, is this truly a fair and inclusive enough basis for insurance arrangements? Also, does a customer who disagrees with the insurance company (and perhaps the digital system) have genuine opportunities for redress, via convenient, non-daunting procedures?

Finally, we found ample illustration that popularising new interactive insurance services requires both consumers' understanding of the benefits and their true excitement and engagement in the co-creative value processes. Accordingly, we call for additional attention to ways in which customer communities could be engaged and guided within the insurance context. That could yield important perspectives for advancing research and practice in this field.

\section{Implications for managerial use}

The research results have significant implications for insurance companies, including lessons for practice. With tools for identifying reasons behind consumer reluctance to embrace tracking-based interactive insurance, insurers can refine their services' design. In particular, they gain information on how to plan and conduct education or marketing communication initiatives so as to increase consumer understanding of interactive insurance and the related benefits, with an eye to decreasing prejudices and negative attitudes. Armed with our findings and framework, managers can direct their focus towards engaging, empowering and leading consumer/customer communities; not just companyinternal operations.

Drawing from our work, managers can also better consider elements that, while not comprehensively analysed in the study or discussed in depth here, are suggested by the findings and point to potential improvements in practice. For example, consumer trust was identified as an important issue. Accordingly, companies could consider ways to give customers greater control and ownership of their personal data. The companies could still use the data to personalise services and inform premiums, but customers would experience greater control of the means of doing so.

\section{References}

Attride-Stirling, J. (2001), "Thematic networks: an analytic tool for qualitative research", Qualitative Research, Vol. 1 No. 3, pp. 385-405.

Baker, D.A. (2020), "Four ironies of self-quantification: wearable technologies and the quantified self", Science and Engineering Ethics, Vol. 26 No. 3, doi: 10.1007/s11948-020-00181-w.

Baker, J., Parasuraman, A., Grewal, D. and Voss, G.B. (2002), "The influence of multiple store environment cues on perceived merchandise value and patronage intentions", Journal of Marketing, Vol. 66 No. 2, pp. 120-141.

Beard, R.E., Pentikäinen, T. and Pesonen, E. (1984), Risk Theory: The Stochastic Basis of Insurance, 3rd ed., Chapman and Hall. 
Becher, S. (2016), "Wearables - a new chance for private insurance companies from the underwriting view”, Zeitschrift für die gesamte Versicherungswissenschaft, Vol. 105 No. 5, pp. 563-565.

Bhattacherjee, A. and Sanford, C. (2006), "Influence processes for information technology acceptance: an elaboration likelihood model”, MIS Quarterly, Vol. 30 No. 4, pp. 805-825.

Bieck, C. and Tjioe, L. (2015), "Capturing hearts, minds and market share - how connected insurers are improving customer retention", available at: www.ibm.com/downloads/cas/VWVGDELZ (accessed 5 May 2020).

Braun, V. and Clarke, V. (2006), "Using thematic analysis in psychology", Qualitative Research in Psychology, Vol. 3 No. 2, pp. 77-101.

Bunker, M. and Ball, A.D. (2009), "Consequences of customer powerlessness: secondary control", Journal of Consumer Behaviour, Vol. 8 No. 5, pp. 268-283.

Carter, M. and Grover, V. (2015), "Me, Myself, and I(T): conceptualizing information technology identity and its implications", MIS Quarterly, Vol. 39 No. 4, pp. 931-958.

Chen, S.Q., Sun, N., Ge, W., Su, J.E. and Li, Q.R. (2019), "The development process of self-acceptance among Chinese women with breast cancer", Japan Journal of Nursing Science, Vol. 17 No. 2, doi: $10.1111 /$ jjns.12308.

Cheung, R. and Vogel, D. (2013), "Predicting user acceptance of collaborative technologies: an extension of the technology acceptance model for e-learning", Computers and Education, Vol. 63, pp. 160-175.

Crawford, K., Lingel, J. and Karppi, T. (2015), “Our metrics, ourselves: a hundred years of self-tracking from the weight scale to the wrist wearable device", European Journal of Cultural Studies, Vol. 18 Nos 4/5, pp. 479-496.

Csíkszentmihályi, M. and Rochberg-Halton, E. (1981), The Meaning of Things: Domestic Symbols and the Self, Cambridge University Press, England.

Dart, A. (2015), "The case for connected wearables in insurance", Asia Insurance Review, available at: www.asiainsurancereview.com/Magazine/ReadMagazineArticle?aid=35855\&aid=35855 (accessed 12 May 2020).

Daykin, C.D., Pentikainen, T. and Pesonen, M. (1994), Practical Risk Theory for Actuaries, Chapman and Hall, London, England.

Desyllas, P. and Sako, M. (2013), "Profiting from business model innovation: evidence from pay-as-youdrive auto insurance", Research Policy, Vol. 42 No. 1, pp. 101-116.

Dubois, A. and Gadde, L.E. (2002), "Systematic combining: an abductive approach to case research", Journal of Business Research, Vol. 55 No. 7, pp. 553-560.

Fuchs, C., Prandelli, E. and Schreier, M. (2010), "The psychological effects of empowerment strategies on consumers' product demand", Journal of Marketing, Vol. 74 No. 1, pp. 65-79.

Geer, J.G. (1988), “What do open-ended questions measure?”, Public Opinion Quarterly, Vol. 52 No. 3, pp. 365-367.

Gidaris, C. (2019), "Surveillance capitalism, datafication, and unwaged labour: the rise of wearable fitness devices and interactive life insurance", Surveillance and Society, Vol. 17 Nos 1/2, pp. 132-138.

Giddens, L., Gonzalez, E. and Leidner, D. (2016), "I track, therefore I am: exploring the impact of wearable fitness devices on employee identity and well-being", paper presented at the Americas Conference on Information Systems, 11-14 August, San Diego, CA.

Hair, J.F., Barth, K., Neubert, D. and Sarstedt, M. (2016), "Examining the role of psychological ownership and feedback in customer empowerment strategies", Journal of Creating Value, Vol. 2 No. 2, pp. 194-210.

Harrison, T. (2002), "Consumer empowerment in financial services: rhetoric or reality?", Journal of Financial Services Marketing, Vol. 7 No. 1, pp. 6-9. 
JICES
19,4

Hofacker, C.F., de Ruyter, K., Lurie, N.H., Manchanda, P. and Donaldson, J. (2016), “Gamification and mobile marketing effectiveness", Journal of Interactive Marketing, Vol. 34, pp. 25-36.

Jonsen, K. and Jehn, K.A. (2009), "Using triangulation to validate themes in qualitative studies", Qualitative Research in Organizations and Management: An International Journal, Vol. 4 No. 2, pp. 123-150.

Jung Choo, H., Moon, H., Kim, H. and Yoon, N. (2012), "Luxury customer value”, Journal of Fashion Marketing and Management: An International Journal, Vol. 16 No. 1, pp. 81-101.

Kamptner, N.L. (1989), "Personal possessions and their meanings in old age", in Spacapan, S. and Oskamp, S. (Eds), The Social Psychology of Aging, SAGE, London, England, pp. 165-196.

Kim, H.W., Chan, H.C. and Gupta, S. (2007), "Value-based adoption of mobile internet: an empirical investigation”, Decision Support Systems, Vol. 43 No. 1, pp. 111-126.

Kim, Y., Park, Y. and Choi, J. (2017), "A study on the adoption of IoT smart home service: using valuebased adoption model”, Total Quality Management and Business Excellence, Vol. 28 Nos 9/10, pp. 1149-1165.

Kumar, N.A. and Yellampalli, S. (2018), "Disruptive innovation for auto insurance entrepreneurs: new paradigm using telematics and machine learning", in Khajehelan, D., Friedrichsen, M. and Mödinger, W. (Eds), Competitiveness in Emerging Markets, Springer, Cham, Switzerland, pp. 555-568.

Lambert, E.V., da Silva, R., Fatti, L., Patel, D., Kolbe-Alexander, T., Derman, W., Noach, A., Nossel, C. and Gaziano, T. (2009), "Fitness-related activities and medical claims related to hospital admissions - South Africa, 2006”, Preventing Chronic Disease, Vol. 6 No. 4, paper A120.

Langley, M.R. (2015), "Hide your health: addressing the new privacy problem of consumer wearables", The Georgetown Law Journal, Vol. 103 No. 6, pp. 1641-1659.

Laukkanen, T. (2007), "Internet vs mobile banking: comparing customer value perceptions", Business Process Management Journal.

Ledger, D. and McCaffrey, D. (2014), "Inside wearables: how the science of human behavior change offers the secret to long-term engagement", white paper (No. 200), Endeavour Partners.

Litman, T. (2005), "Pay-as-you-drive pricing and insurance regulatory objectives", Journal of Insurance Regulation, Vol. 23 No. 3, pp. 35-53.

Lupton, D. (2016), "The diverse domains of quantified selves: self-tracking modes and dataveillance", Economy and Society, Vol. 45 No. 1, pp. 101-122.

McCrea, M. and Farrell, M. (2018), "A conceptual model for pricing health and life insurance using wearable technology”, Risk Management and Insurance Review, Vol. 21 No. 3, pp. 389-411.

Maas, P. and Rüfenacht, M. (2018), "Creating customer value in insurance markets - research perspectives and managerial relevance", International Journal of Bank Marketing, Vol. 36 No. 6, pp. 1010-1014.

Mathwick, C., Malhotra, N. and Rigdon, E. (2001), “Experiential value: conceptualization, measurement and application in the catalog and internet shopping environment", Journal of Retailing, Vol. 77 No. 1, pp. 39-56.

Meister, A., Sinclair, A. and Jehn, K.A. (2015), “Don’t put me in that box!': women leaders navigating identity asymmetries at work", Academy of Management Proceedings, Vol. 2015 No. 1, paper 10519, doi: 10.5465/ambpp.2015.90.

Mohr, J.J. and Fassinger, R.E. (2003), "Self-acceptance and self-disclosure of sexual orientation in lesbian, gay, and bisexual adults: an attachment perspective”, Journal of Counseling Psychology, Vol. 50 No. 4, pp. 482-495.

Patel, D., Lambert, E.V., da Silva, R., Greyling, M., Kolbe-Alexander, T., Noach, A. and Gaziano, T. (2011), "Participation in fitness-related activities of an incentive-based health promotion program and hospital costs: a retrospective longitudinal study", American Journal of Health Promotion, Vol. 25 No. 5, pp. 341-348. 
Patel, D.N., Lambert, E.V., da Silva, R., Greyling, M., Nossel, C., Noach, A. and Gaziano, T. (2010), "The association between medical costs and participation in the vitality health promotion program among 948,974 members of a South African health insurance company", American Journal of Health Promotion, Vol. 24 No. 3, pp. 199-204.

Peverelli, R. and de Feniks, R. (2010), Reinventing Financial Services: What Consumers Expect from Future Banks and Insurers, Pearson Education.

Reja, U., Manfreda, K.L., Hlebec, V. and Vehovar, V. (2003), “Open-ended vs. close-ended [sic] questions in web questionnaires", Developments in Applied Statistics, Vol. 19 No. 1, pp. 159-177.

Riikkinen, M., Saarijärvi, H., Sarlin, P. and Lähteenmäki, I. (2018), "Using artificial intelligence to create value in insurance", International Journal of Bank Marketing.

Rintamäki, T., Kanto, A., Kuusela, H. and Spence, M.T. (2006), "Decomposing the value of department store shopping into utilitarian, hedonic and social dimensions", International Journal of Retail and Distribution Management, Vol. 34 No. 1, pp. 6-24.

Rintamäki, T., Kuusela, H. and Mitronen, L. (2007), "Identifying competitive customer value propositions in retailing", Managing Service Quality: An International Journal, Vol. 17 No. 6 , pp. 621-634.

Sardi, L., Idri, A. and Fernández-Alemán, J.L. (2017), “A systematic review of gamification in e-health”, Journal of Biomedical Informatics, Vol. 71, pp. 31-48.

Shaikh, A.A. and Karjaluoto, H. (2015), "Mobile banking adoption: a literature review", Telematics and Informatics, Vol. 32 No. 1, pp. 129-142.

Sheth, J.N., Newman, B.I. and Gross, B.L. (1991), "Why we buy what we buy: a theory of consumption values", Journal of Business Research, Vol. 22 No. 2, pp. 159-170.

Similä, H., Immonen, M., Toska-Tervola, J., Enwald, H., Keränen, N., Kangas, M., Jämsä, T. and Korpelainen, R. (2018), "Feasibility of mobile mental wellness training for older adults", Geriatric Nursing, Vol. 39 No. 5, pp. 499-505.

Soleymanian, M., Weinberg, C.B. and Zhu, T. (2019), "Sensor data and behavioral tracking: does usagebased auto insurance benefit drivers?", Marketing Science, Vol. 38 No. 1, pp. 21-43.

Tuckett, A.G. (2005), "Applying thematic analysis theory to practice: a researcher's experience", Contemporary Nurse, Vol. 19 Nos 1/2, pp. 75-87.

Voutilainen, R. and Koskinen, L. (2017), “Customers' opinions on incentive based insurance”, Journal of Insurance and Financial Management, Vol. 3 No. 1.

Wessels, L. and Drennan, J. (2010), "An investigation of consumer acceptance of M-banking", International Journal of Bank Marketing.

\section{Corresponding author}

Antti Talonen can be contacted at: antti.talonen@helsinki.fi

For instructions on how to order reprints of this article, please visit our website: 